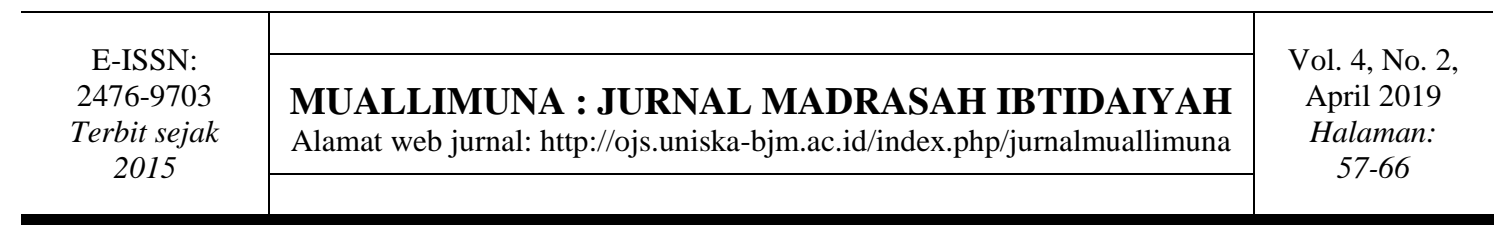

\title{
PENINGKATKAN KETERAMPILAN BERPIKIR KRITIS DAN SIKAP ILMIAH PESERTA DIDIK MELALUI MODEL INKUIRI TERBIMBING
}

\author{
Dyah Pramesti Fauzia ${ }^{1}$, Badarudin $^{2}$, Supriatna $^{3}$ \\ 1,2,3 PGSD, Universitas Muhammadiyah Purwokerto \\ 1pramestidyah67@gmail.com, ${ }^{2}$ badarudin@ump.ac.id, ${ }^{3}$ supriatna_19@yahoo.com
}

\begin{abstract}
Abstrak: Penelitian ini dilator belakangi oleh rendahnya keterampilan berpikir kritis dan sikap ilmiah peserta didik. Oleh karena itu, penelitian ini bertujuan untuk meningkatkan keterampilan berpikir kritis dan sikap ilmiah peserta didik melalui model Inkuiri Terbimbing. Jenis penelitian ini adalah Penelitian Tindakan Kelas (PTK). Penelitian tindakan kelas ini dilaksanakan dalam 2 (dua) siklus, masing-masing siklus terdiri dari dua pertemuan dengan masing-masing pertemuan satu rencana pembelajaran. Penelitian ini terdiri dari tahapan perencanaan, tindakan, observasi dan refleksi. Subjek Penelitian ini adalah peserta didik Kelas VA SDN 1 Pajerukan yang berjumlah 25 peserta didik yang terdiri dari 11 peserta didik laki-laki dan 14 peserta didik perempuan. Alat pengumpulan data menggunakan tes keterampilan berpikir kritis, lembar aktivitas guru, lembar aktivitas peserta didik, lembar observasi sikap ilmiah peserta didik serta lembar skala sikap ilmiah peserta didik. Hasil peningkatan yang terjadi dapat dilihat pada setiap siklusnya. Hasil penelitian ini menunjukkan bahwa penggunaan model Inkuiri Terbimbing dapat meningkatkan keterampilan berpikir kritis dan sikap ilmiah peserta didik pada tema 7 Peristiwa Dalam Kehidupan di kelas VA SDN 1 Pajerukan.
\end{abstract}

Kata Kunci: Keterampilan Berpikir Kritis; Sikap Ilmiah; Model Inkuiri Terbimbing

\section{IMPROVING CRITICAL THINKING SKILLS AND SCIENTIFIC ATTITUDES OF STUDENTS THROUGH GUIDED-INQUIRY MODEL}

Abstract: The background of this research is the low critical thinking skills and scientific attitudes of students. So that, this study aims to improve the Guided Inquiry model. This type of research is Classroom Action Research (CAR). This classroom action research is carried out in 2 (two) cycles, each cycle consisting of two meetings with each meeting of one lesson plan. This study consists of stages of planning, action, observation of critical thinking skills and scientific attitudes of students through reflection. The subjects of this study were 25th grade students of SDN 1 Pajerukan, consisting of 11 students consisting of 11 male students and 14 female students. The data collection tool uses tests of critical thinking skills, teacher activity sheets, student activity sheets, observation sheets, scientific attitudes of students, and scientific attitude scale sheets of students. The results of the improvements that occur can be seen in each cycle. The results of this study indicate that the use of modes can improve the critical thinking skills and scientific attitudes of students on the theme of 7 Events in Life in the VA class at SDN 1 Pajerukan.

Keywords: Critical Thinking Skills; Scientific Attitudes; Guided Inquiry Model 


\section{PENDAHULUAN}

Pendidikan merupakan landasan dalam pengembangan praktik pendidikan yaitu pengembangan kurikulum. Perubahan kurikulum dari kurikulum 2006 ke kurikulum 2013 dikarenakan pendidikan di Indonesia masih rendah dan cukup tertinggal dengan negaranegara lain. Hal tersebut sesuai dengan Undang-Undang Nomor 57 Tahun 2014 Pasal 1 menyebutkan bahwa kurikulum pada Sekolah Dasar/Madrasah Ibtidaiyah yang telah dilaksanakan sejak tahun 2013/2014 disebut Kurikulum 2013 Sekolah Dasar/Madrasah Ibtidaiyah. Mulyasa (2013: 7) menyatakan bahwa kurikulum 2013 lebih menekankan pada pendidikan karakter terutama pada tingkat dasar yang akan menjadi pondasi pada tingkat berikutnya.

Keterampilan berpikir kritis merupakan salah satu komponen dalam tantangan abad ke-21 dan keterampilan yang dibutuhkan pada kurikulum 2013. Menurut Susanto (2015: 121) berpikir kritis yaitu suatu kegiatan melalui cara berpikir tentang ide atau gagasan yang berhubungan dengan konsep yang diberikan atau masalah yang dipaparkan. Tujuan dari berpikir kritis adalah untuk mencapai pemahaman yang mendalam sehingga membuat seseorang mengerti maksud dibalik ide atau suatu kejadian (Ariani, 2018).

Selain itu, pembelajaran tematik juga berpengaruh positif terhadap sikap peserta didik. Sikap peserta didik terbentuk dari pendekatan ilmiah yang dilakukan selama proses pembelajaran. Sukaesi dalam Haryadi (2016: 2) menjelaskan bahwa penanaman sikap ilmiah melalui model pembelajaran yang tepat sangat berpengaruh terhadap konsep atau topik yang dipelajari. Sikap ilmiah berpengaruh terhadap keseimbangan antara hard skill dan soft skill.

Berdasarkan hasil observasi yang dilakukan di kelas VA di SD Negeri 1 Pajerukan dalam proses pembelajaran yang dilaksanakan menunjukan beberapa permasalahan yang dialami baik oleh guru maupun peserta didik. Permasalahan yang dialami oleh guru yaitu sulitnya mengatur waktu pembelajaran karena materi yang akan disampaikan terlalu banyak sehingga guru kurang melibatkan peserta didik selama proses pembelajaran. Guru masih menggunakan model yang konvensional sehingga kurang mengaitkan materi dengan konsep yang nyata kehidupan sehingga peserta didik kurang mengembangkan pengetahuan. Pada saat diberikan pertanyaan oleh guru peserta didik belum mampu menganalisis pertanyaan yang diberikan Pembelajaran masih berpusat pada guru sehingga peserta didik kurang aktif dalam mengemukakan pendapatnya tentang masalah atau pertanyaan yang diberikan dan saat temannya memberikan pendapat peserta didik lain kurang menghargai pendapat teman salah satunya yaitu tidak mendengarkan teman ketika berpendapat.

Permasalahan yang dialami oleh peserta didik yaitu peserta didik masih kurang aktif selama proses pembelajaran dan masih senang dengan bermain sehingga sulit berkonsentrasi saat mengikuti pembelajaran. Selain itu, kurangnya rasa ingin tahu yang tinggi terhadap materi pembelajaran yang sedang dilakukan sehingga peserta didik merasa kurang percaya diri ketika mengajukan pertanyaan atau mengemukakan pendapatnya dan kurang menghargai pendapat yang disampaikan oleh temannya. Beberapa permasalahan tersebut seringkali terjadi pada setiap proses pembelajaran berlangsung. Peserta didik belum mampu mengumpulkan informasi berdasarkan materi yang disampaikan oleh guru karena peserta didik masih menganggap guru sebagai sumber belajar. Peserta didik belum mampu menyimpulkan materi pelajaran dari hasil pembelajaran dengan menggunakan bahasa sendiri. Kurangnya melakukan percobaan sehingga peserta didik memiliki sikap menyelidiki yang kurang dan rendahnya keingintahuan terhadap sesuatu yang baru. 
Berdasarkan hasil diskusi dengan guru kelas maka peneliti berkolaborasi untuk mengatasi permasalahan menggunakan model Inkuiri Terbimbing pada tema 7 Peristiwa Dalam Kehidupan merupakan salah satu solusi yang dapat diterapkan untuk meningkatkan keterampilan berpikir kritis dan sikap ilmiah. Model pembelajaran inkuiri terbimbing dapat melatih peserta didik berpikir kritis dan sikap ilmiah agar dapat mengembangkan kemampuan memecahkan masalah. Inasyah (2013: 3) menjelaskan bahwa model pembelajaran inkuiri terbimbing merupakan model yang melatih peserta didik dalam proses menginvestigasi dan menjelaskan suatu fenomena yang tidak biasa dengan bimbingan guru. Dewi (2013: 2) menjelaskan bahwa model inkuiri terbimbing menekankan pada proses penemuan sehingga memunculkan sikap ilmiah peserta didik. Selain itu, model pembelajaran inkuiri terbimbing dapat membuat proses pembelajaran lebih bermakna karena dalam model tersebut telah mencakup aspek afektif, kognitif dan psikomotor.

Berdasarkan latar belakang tersebut, maka peneliti berkolaborasi dengan guru akan melakukan penelitian yang berjudul "Upaya Meningkatkan Keterampilan Berpikir Kritis dan Sikap Ilmiah Peserta Didik Melalui Model Inkuiri Terbimbing pada Kelas VA Tema 7 Peristiwa Dalam Kehidupan di SD Negeri 1 Pajerukan”. Adapun inovasi dalam penelitian ini adalah dengan diterapkannya model Inkuiri Terbimbing akan membantu peserta didik dalam mengembangkan keterampilan berpikir kritis dan sikap ilmiah agar dapat memecahkan permasalahan dengan mengaitkan materi yang dipelajari dengan percobaan yang dilakukan.

Perumusan masalah pada penelitian ini yaitu "Bagaimanakah model pembelajaran Inkuiri Terbimbing dapat meningkatkan keterampilan berpikir kritis dan sikap ilmiah peserta didik pada tema 7 Peristiwa Dalam Kehidupan di kelas VA SD Negeri 1 Pajerukan?”. Tujuan penelitian yang ingin dicapai adalah mengkaji secara mendalam peningkatan keterampilan berpikir kritis dan sikap ilmiah peserta didik pada tema 7 Peristiwa Dalam Kehidupan di kelas VA SD Negeri 1 Pajerukan.

\section{METODE}

Penelitian ini merupakan penelitian tindakan kelas yang dilaksanakan di SD Negeri 1 Pajerukan pada Semester II Tahun Ajaran 2018/2019. Subjek penelitian adalah siswa kelas VA berjumlah 25 siswa yang terdiri dari 14 siswa laki-laki dan 11 peserta didik perempuan.

Penelitian ini menggunakan model PTK Kemmis dan Mc Taggart sebagaimana dikutip oleh Jumiati (2017), langkah-langkahnya terdiri dari perencanaan, tindakan, observasi dan refleksi. Teknik pengumpulan data dalam penelitian ini dengan menggunakan teknik tes dan teknik non tes. Teknik tes berupa tes uraian. Teknik non tes terdiri dari observasi, angket sikap dan dokumentasi. Alat pengumpulan data menggunakan tes uraian sesuai dengan indikator keterampilan berpikir kritis, lembar angket, lembar observasi (lembar observasi guru, lembar observasi peserta didik dan lembar sikap ilmiah peserta didik) dan dokumentasi. 


\section{HASIL DAN PEMBAHASAN \\ Hasil}

Hasil penelitian ini menemukan bahwa terdapat peningkatan berpikir kritis dan sikap ilmiah peserta didik melalui model inkuiri terbimbing. Hal tersebut dibuktikan dengan hasil tes keterampilan berpikir kritis peserta didik dan meningkatnya rasa ingin tahu peserta didik terhadap pembelajaran sehingga proses pembelajaran lebih bermakna. Untuk mengukur keterampilan berpikir kritis, peserta didik diberikan soal tes tertulis uraian dengan jumlah soal 5 butir soal uraian yang dibatasi waktu dalam setiap pengerjaan soalnya yaitu 3 menit. Soal uraian tersebut dibuat berdasarkan indikator keterampilan berpikir kritis. Peningkatan hasil keterampilan berpikir kritis dapat dilihat pada tabel 1 dibawah ini.

Tabel 1. Peningkatan Keterampilan Berpikir Kritis

\begin{tabular}{llcc}
\hline No & Indikator Keterampilan Berpikir Kritis & Siklus I & Siklus II \\
\hline 1. & Memberikan penjelasan sederhana & 2,7 & 3.26 \\
\hline 2. & Membangun keterampilan dasar & 3,2 & 4.04 \\
\hline 3. & Membuat inverensi/ menyimpulkan & 2,98 & 3.28 \\
\hline 4. & Memberikan penjelasan lebih lanjut & 2,72 & 3.9 \\
\hline 5. & Mengatur strategi dan taktik & 3,04 & 3.96 \\
\hline Jumlah & $\mathbf{2 9 , 2 8}$ & 36,88 \\
\hline Rata-Rata & $\mathbf{2 , 9}$ & $\mathbf{3 , 6 5}$ \\
\hline Kriteria & Kurang Baik & Baik \\
\hline
\end{tabular}

Tabel 1 di atas menunjukkan bahwa nilai rata-rata siswa pada lima indikator keterampilan berpikir kritis telah mengalami peningkatan dari siklus satu ke siklus dua, yaitu pada indikator 1 mengalami peningkatan sebesar 0,56 , pada indikator 2 mengalami peningkatan sebesar 0,84 , pada indikator 3 mengalami peningkatan sebesar 0,3 , pada indikator 4 mengalami peningkatan sebesar 1,18, dan pada indikator 5 mengalami peningkatan sebesar 0,92 . Indikator yang mengalami peningkatan secara signifikan yaitu pada indikator keempat memberikan penjelasan lebih lanjut, hal tersebut dikarenakan peserta didik dapat menganalisis penjelasan menurut pemahaman mereka sendiri dari pembelajaran yang telah dilakukan.

Hasil sikap ilmiah peserta didik diperoleh dari pengamatan hasil observasi sikap ilmiah peserta didik, aktivitas peserta didik saat proses pembelajaran di dalam kelas dan hasil angket/ skala sikap ilmiah peserta didik. Angket sikap ilmiah diberikan kepada peserta didik pada pertemuan kedua atau diakhir siklus. Sikap ilmiah peserta didik mengalami peningkatan setelah menggunakan model pembelajaran Inkuiri Terbimbing siklus I ke siklus II. Hasil presentase nilai rata-rata hasil sikap ilmiah berkaitan dengan Tema 7 Peristiwa dalam Kehidupan Kelas V A SDN 1 Pajerukan dapat dilihat pada tabel 2 berikut. 
Tabel 2. Skala Sikap Ilmiah Peserta Didik

\begin{tabular}{|c|c|c|c|c|}
\hline No & Indikator & Pernyataan & Siklus I & Siklus II \\
\hline \multirow[t]{4}{*}{1.} & \multirow[t]{4}{*}{ Objektif/Jujur } & $\begin{array}{l}\text { Ketika mengerjakan soal latihan yang diberikan } \\
\text { oleh guru saya yakin dengan jawaban saya sendiri }\end{array}$ & 4,0 & 4.8 \\
\hline & & $\begin{array}{l}\text { Ketika mengerjakan soal yang diberikan oleh guru } \\
\text { saya merasa bosan }\end{array}$ & 3,8 & 4.6 \\
\hline & & $\begin{array}{l}\text { Ketika mengerjakan soal ulangan, saya melihat } \\
\text { pekerjaan teman }\end{array}$ & 4,0 & 4.6 \\
\hline & & Objektif terhadap data yang didapat & 3,52 & 4.6 \\
\hline \multirow[t]{4}{*}{2.} & \multirow{4}{*}{$\begin{array}{c}\text { Toleran / } \\
\text { Menghargai } \\
\text { pendapat orang } \\
\text { lain }\end{array}$} & $\begin{array}{l}\text { Bersedia menerima pendapat / usulan orang lain } \\
\text { saat berdiskusi. }\end{array}$ & 4,0 & 4.7 \\
\hline & & $\begin{array}{l}\text { Saya malas berdiskusi untuk mencari kesepakatan } \\
\text { atas perbedaan pendapat dalam kelompok }\end{array}$ & 4 & 4.6 \\
\hline & & $\begin{array}{l}\text { Pada saat guru maupun teman sedang berbicara dan } \\
\text { mengemukakan pendapatnya saya mendengarkan } \\
\text { dengan memperhatikan dengan sungguh-sungguh. }\end{array}$ & 3.8 & 4.7 \\
\hline & & $\begin{array}{l}\text { Saya suka memotong pembicaraan teman saat } \\
\text { diskusi. }\end{array}$ & 3.8 & 4.5 \\
\hline \multirow[t]{4}{*}{3.} & \multirow{4}{*}{$\begin{array}{l}\text { Sikap ingin } \\
\text { menyelidiki atau } \\
\text { keingintahuan } \\
\text { yang tingi }\end{array}$} & $\begin{array}{l}\text { Saya senang bertanya kepada guru jika ada materi } \\
\text { yang belum saya pahami. }\end{array}$ & 3.8 & 4.7 \\
\hline & & $\begin{array}{l}\text { Jika guru bertanya seputar pelajaran, saya lebih } \\
\text { memilih diam. }\end{array}$ & 2.9 & 4,6 \\
\hline & & $\begin{array}{l}\text { Mencari jawaban dari sumber lain apabila } \\
\text { mengalami kesulitan. }\end{array}$ & 2,6 & 4,0 \\
\hline & & $\begin{array}{l}\text { Saya bersikap acuh (atau tidak memperhatikan) } \\
\text { ketika guru menjelaskan pada saat pembelajaran } \\
\text { berlangsung }\end{array}$ & 4,0 & 4.5 \\
\hline \multirow[t]{4}{*}{4.} & \multirow[t]{4}{*}{ Bekerja sama } & $\begin{array}{l}\text { Saya bekerja sama dengan solid dalam setiap } \\
\text { kegiatan pembelajaran. }\end{array}$ & 3.4 & 4.7 \\
\hline & & $\begin{array}{l}\text { Jika saya dan seorang teman dalam satu kelompok } \\
\text { sama-sama mengalami kesulitan, saya belum tentu } \\
\text { membantunya. }\end{array}$ & 3.3 & 4,4 \\
\hline & & $\begin{array}{l}\text { Saya senang berbagi tugas dengan anggota } \\
\text { kelompok. }\end{array}$ & 3,1 & 4.6 \\
\hline & & $\begin{array}{l}\text { Jika anggota kelompok tidak sependapat dengan } \\
\text { saya, saya akan mengerjakan sendiri. }\end{array}$ & 3.9 & 4.5 \\
\hline \multicolumn{2}{|c|}{ Jumlah } & & 1464 & 1849 \\
\hline \multicolumn{2}{|c|}{ Rata-Rata } & & 3,66 & 4,62 \\
\hline \multicolumn{2}{|c|}{ Kriteria } & & Baik & $\begin{array}{l}\text { Sangat } \\
\text { Baik }\end{array}$ \\
\hline
\end{tabular}

Hasil sikap ilmiah peserta didik berdasarkan tabel 2 menunjukkan bahwa adanya peningkatan nilai rata-rata dari siklus I ke siklus II melalui model pembelajaran Inkuiri Terbimbing pada siklus I dapat dikategorikan ke dalam kriteria baik dan pada siklus II terjadi peningkatan dengan kriteria sikap ilmiah sangat baik. Hal tersebut diperkuat dengan hasil observasi sikap ilmiah peserta didik kelas V A SDN 1 Pajerukan dapat dilihat pada tabel 3 berikut. 
Tabel 3. Observasi Sikap Ilmiah Peserta Didik

\begin{tabular}{|c|c|c|c|c|c|}
\hline \multirow{2}{*}{ No } & \multirow{2}{*}{ Pernyataan } & \multicolumn{2}{|c|}{ Rata-Rata } & \multirow{2}{*}{ Jml } & \multirow{2}{*}{ Rata-Rata } \\
\hline & & Siklus I & Siklus II & & \\
\hline & Objektif/jujur dalam pembelajaran & 3,34 & 4,28 & 7.62 & 3.81 \\
\hline 2. & Toleran/Menghargai pendapat orang lain & 3,58 & 4,5 & 8.08 & 4.04 \\
\hline 3. & $\begin{array}{l}\text { Sikap ingin menyelidiki atau keingintahuan yang tingi } \\
\text { terhadap sesuatu }\end{array}$ & 3,22 & 3,92 & 7.14 & 3.57 \\
\hline 4. & $\begin{array}{llll}\begin{array}{l}\text { Bekerja sama dengan } \\
\text { pembelajaran }\end{array} & \text { kelompok pada saat } \\
\end{array}$ & 3,8 & 4,7 & 8.5 & 4.25 \\
\hline \multicolumn{2}{|c|}{ Jumlah } & 27,88 & $\mathbf{3 4 , 8}$ & \multicolumn{2}{|r|}{62.68} \\
\hline \multicolumn{2}{|c|}{ Rata-Rata } & 3,48 & 4,35 & \multicolumn{2}{|r|}{3.9} \\
\hline \multicolumn{2}{|c|}{ Kriteria } & Baik & $\begin{array}{l}\text { Sangat } \\
\text { Baik }\end{array}$ & \multicolumn{2}{|r|}{ Baik } \\
\hline
\end{tabular}

Hasil observasi sikap ilmiah peserta didik berdasarkan tabel 3 menunjukkan bahwa adanya peningkatan rata-rata dari siklus I ke siklus II melalui model pembelajaran Inkuiri Terbimbing. Rata-rata hasil observasi sikap ilmiah peserta didik diperoleh setelah melaksanakan pembelajaran menggunakan model pembelajaran Inkuiri Terbimbing, pada siklus I jumlah rata-rata yang diperoleh adalah 3,48 dengan kriteria baik, sedangkan pada siklus II mengalami peningkatan jumlah rata-rata yaitu 4,35 dengan kriteria sangat baik. Dari kedua siklus tersebut diperoleh rata-rata keseluruhan hasil observasi sikap ilmiah peserta didik kelas IIV A SDN 1 Pajerukan adalah 3,9 dengan kriteria baik. Hal tersebut dikarenakan peserta didik memiliki sikap ingin tahu yang besar terhadap proses pembelajaran. Sehingga proses pembelajaran yang dilakukan lebih bermakna dan memberikan pengaruh terhadap tes keterampilan berpikir kritis maupun permasalahan yang diberikan pada saat pembelajaran.

\section{Pembahasan}

Mengacu pada rumusan masalah penelitian maka hasil penelitian ini terdiri dari dua bagian berikut.

\section{1) Peningkatan Keterampilan Berpikir Kritis Peserta Didik}

Pada saat Penelitian Tindakan Kelas (PTK) keterampilan berpikir kritis dilakukan menggunakan tes uraian yang disesuaikan dengan indikator keterampilan berpikir kritis peserta didik. Soal tes keterampilan berpikir kritis terdiri dari 5 soal uraian yang disesuaikan dengan indikator keterampilan berpikir kritis, setiap soal yang diberikan diberikan waktu pengerjaan selama 3 menit. Susanto (2015: 125) menyatakan bahwa indikator keterampilan berpikir kritis yaitu 1) memberikan penjelasan sederhana, 2) membangun keterampilan dasar, 3) membuat inverensi/ menyimpulkan, 4) memberikan penjelasan lebih lanjut, 5) mengatur strategi dan taktik. Adapun hasil perolehan skor ratarata keterampilan berpikir kritis peserta didik setiap indikator adalah:

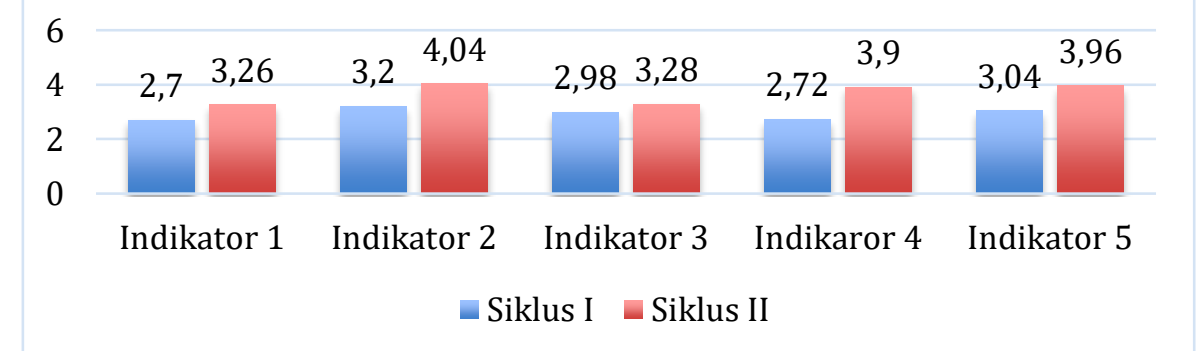

Gambar 1 Diagram Nilai Tes Keterampilan Berpikir Kritis Peserta Didik Tiap Indikator Kelas VA SD Negeri 1 Pajerukan 
Berdasarkan gambar 1 menunjukkan adanya peningkatan hasil tes keterampilan berpikir kritis tiap indikator, yaitu indikator 1) yaitu memberikan penjelasan sederhana, pada siklus I diperoleh skor rata-rata 2,7 dengan kriteria kurang baik dan pada siklus II diperoleh skor rata-rata 3,26 dengan kriteria kurang baik. Hasil tes keterampilan berpikir kritis indikator 2) yaitu membangun keterampilan dasar, pada siklus I diperoleh skor ratarata 3,2 dengan kriteria kurang baik dan pada siklus II diperoleh skor rata-rata 4,04 dengan kriteria baik. Hasil tes keterampilan berpikir kritis indikator 3) yaitu membuat inverensi/ menyimpulkan, pada siklus I diperoleh skor rata-rata 2,98 dengan kriteria kurang baik dan pada siklus II diperoleh skor rata-rata 3,28 dengan kriteria kurang baik. Hasil tes keterampilan berpikir kritis indikator 4) yaitu memberikan penjelasan lebih lanjut, pada siklus I diperoleh skor rata-rata 2,72 dengan kriteria kurang baik dan pada siklus II diperoleh skor rata-rata 3,9 dengan kriteria baik. Hasil tes keterampilan berpikir kritis indikator 5) yaitu mengatur strategi dan taktik, pada siklus I diperoleh skor rata-rata 3,04 dengan kriteria kurang baik dan pada siklus II diperoleh skor rata-rata 3,96 dengan kriteria baik.

Penggunaan model Inkuiri Terbimbing berdampak baik pada pembelajaran, terbukti peserta didik mampu meningkatkan keterampilan berpikirnya untuk memecahkan permasalahan yang diberikan. Model inkuiri menurut Hosnan (2014: 341) yang menjelaskan bahwa pada pembelajaran inkuiri merupakan rangkaian kegiatan pembelajaran yang menekankan pada proses berpikir kritis dan analitis untuk mencari dan menemukan sendiri jawaban dari suatu masalah yang dipertanyakan. Berpikir kritis tidak hanya melibatkan logika namun juga mendapatkan pengetahuan berdasarkan percobaan yang dilakukan. Nurmala (2018: 46) menjelaskan bahwa berpikir kritis merupakan proses dimana pengetahuan dan keterampilan dikerahkan dalam memecahkan masalah yang muncul, mengambil keputusan, dan melalukan investigasi berdasarkan data yang didapat dan mendapat informasi yang diinginkan. Peningkatan keterampilan berpikir kritis peserta didik kelas VA SD Negeri 1 Pajerukan siklus I dan siklus II, yaitu:

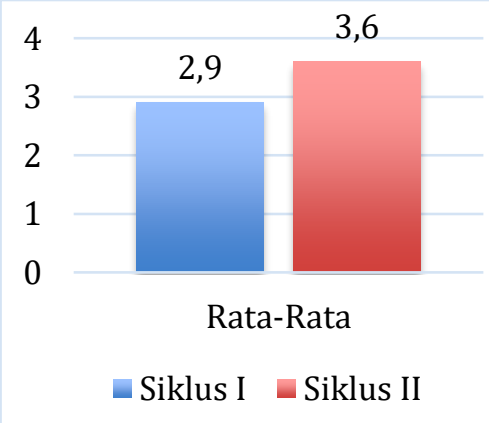

\section{Gambar 2 Diagram Hasil Keterampilan Berpikir Kritis Peserta Didik}

Berdasarkan gambar 2 menunjukkan terjadi peningkatan keterampilan berpikir kritis peserta didik dari siklus I ke siklus II. Pada gambar tersebut, hasil rata-rata keterampilan berpikir kritis peserta didik dari siklus I dan siklus II mengalami peningkatan yaitu siklus I sebesar 2,9 meningkat pada siklus II menjadi 3,6 termasuk dalam kriteria baik.

Berpikir kritis adalah salah satu jenis berpikir yang konvergen yaitu menuju ke satu titik. Keterampilan berpikir kritis sangat baik bila dilatih terhadap peserta didik khususnya usia Sekolah Dasar. Tilaar (2011:17) menyebutkan ada beberapa pertimbangan penting mengenai berpikir kritis, yaitu: 1) Mengembangkan berpikir kritis 
dalam pendidikan berarti telah memberikan penghargaan kepada peserta didik sebagai pribadi. Peserta didik akan merasa dihargai dan dihormati di dalam sekolah. 2) Berpikir kritis merupakan tujuan yang ideal dalam pendidikan karena mempersiapkan peserta didik untuk kehidupan yang dewasa. Dalam kehidupan tersebut, peserta didik memiliki cara pikir yang berbeda dengan orang lain. 3) Pengembangan berpikir kritis dalam proses pendidikan yaitu suatu cita-cita tradisional seperti yang ingin dicapai melalui pelajaran ilmu-ilmu eksakta dan kealaman serta mata pelajaran yang lain secara tradisinal dianggap mengembangkan berpikir kritis. 4) Berpikir kritis merupakan suatu hal yang dibutuhkan dalam kehidupan demokratis.

\section{2) Peningkatan Sikap Ilmiah Peserta Didik}

Pada saat Penelitian Tindakan Kelas (PTK) sikap ilmiah peserta didik diukur dengan menggunakan lembar observasi sikap ilmiah dan angket skala sikap ilmiah peserta didik. Pada proses pembelajaran guru menyajikan sebuah permasalahan, dari permasalahan tersebut peserta didik dibimbing untuk mencari informasi mengenai permasalahan yang diberikan. Sulistyowati, dkk (2016: 34) menyatakan bahwa sikap ilmiah merupakan kegiatan yang dilakukan oleh seorang ilmuwan yang bisa berupa penelitian dalam rangka mencari kebenaran dari suatu permasalahan. Guru melibatkan peserta didik secara aktif untuk menyelidiki sehingga dapat merumuskan penemuannya sendiri. Haqul (2016:199) menjelaskan bahwa model ini menekankan pada kegiatan peserta didik untuk mencari dan menemukan sendiri dari konsep yang ingin dicari.

Observasi sikap ilmiah peserta didik dilakukan pada setiap pertemuan di setiap siklus. Terjadi peningkatan sikap ilmiah peserta didik kelas VAA menggunakan model inkuiri terbimbing. Hasil observasi sikap ilmiah peserta didik pada siklus I diperoleh jumlah keseluruhan 27,88 dengan nilai rata-rata 3,48 dengan kriteria baik. Pada siklus II diperoleh jumlah keseluruhan 34,8 dengan nilai rata-rata 4,34 dengan kriteria sangat baik. Terjadi peningkatan dari siklus I dan siklus II dari nilai 3,48 menjadi 4,35 yaitu sebesar 0,87 .

Sikap ilmiah tidak hanya diukur menggunakan observasi namun diperkuat menggunakan angket sikap ilmiah yang diberikan pada siklus I pertemuan 2 dan siklus II pertemuan 2 yang diisi oleh peserta didik. Hasil angket sikap ilmiah peserta didik dapat dilihat sebagai berikut:

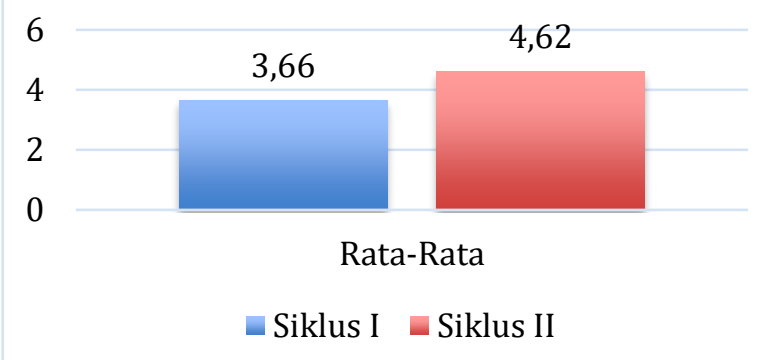

Gambar 3 Diagram Peningkatan Angket Sikap Ilmiah Peserta Didik Kelas VAA SD Negeri 1 Pajerukan

Gambar 3 menunjukkan adanya peningkatan rata-rata angket sikap ilmiah peserta didik pada siklus I yang memperoleh jumlah keseluruhan 1464 dengan rata-rata 3,66 dengan kriteria baik. Siklus II memperoleh jumlah keseluruhan 1849 dengan rata-rata angket sikap ilmiah siklus II yaitu 4,62 dengan kriteria sangat baik. Peningkatan dari siklus I dan siklus II sebesar 0,96. 
Hal ini tidak terlepas dari peranan guru selama proses pembelajaran. Guru memiliki peran penting untuk membimbing peserta didik dalam meningkatkan sikap ilmiah peserta didik selama proses pembelajaran dengan menggunakan langkah-langkah model inkuiri terbimbing pada tema 7 Peristiwa dalam Kehidupan. Andriani (2011:1) menjelaskan model inkuiri terbimbing yaitu guru tidak melepas begitu saja kegiatankegiatan yang dilakukan oleh peserta didik.

\section{PENUTUP}

Berdasarkan hasil Penelitian Tindakan Kelas yang telah dilakukan selama 2 siklus dalam meningkatkan keterampilan berpikir kritis dan sikap ilmiah peserta didik melalui model inkuiri terbimbing pada tema 7 Peristiwa Dalam Kehidupan di kelas VAA SD Negeri 1 Pajerukan telah menunjukkan hasil sesuai dengan yang diharapkan. Hasil penelitian yang diperoleh sebagai berikut:

1) Penerapan model Inkuiri Terbimbing dalam pembelajaran tematik tema 7 Peristiwa Dalam Kehidupan dapat mengingkatkan keterampilan berpikir kritis peserta didik. Peningkatan ini terlihat tidak hanya dari hasil tes keterampilan berpikir kritis yang dikerjakan oleh setiap peserta didik, tetapi juga dari keaktifan guru, cara penyampaian materi oleh guru dan pemahaman peserta didik dalam belajar. Hal tersebut ditunjukan dengan hasil tes keterampilan berpikir kritis yang diperoleh peserta didik yang mengalami peningkatan yaitu pada siklus I memperoleh jumlah skor 29,28 dengan rata-rata 2,9 dan termasuk dalam kriteria kurang baik. Pada siklus II memperoleh jumlah skor 36,88 dengan rata-rata 3,65 dan termasuk dalam kriteria baik.

2) Penerapan model Inkuiri Terbimbing dalam pembelajaran tematik tema 7 Peristiwa Dalam Kehidupan dapat mengingkatkan sikap ilmiah peserta didik. Peningkatan ini terlihat tidak hanya dari hasil angket sikap yang diisi oleh setiap peserta didik, tetapi juga dari keaktifan yang menunjukkan sikap ilmiah peserta didik dalam pembelajaran. Observasi sikap ilmiah peserta didik siklus I memperoleh rata-rata sebesar 3,48 dengan kriteria baik, meningkat pada siklus II menjadi 4,35 dengan kriteria sangat baik. Sedangkan, skala sikap ilmiah peserta didik yang diisi oleh peserta didik pada siklus I memperoleh rata-rata 3,66 dengan kriteria baik, meningkat pada siklus II menjadi 4,62 dengan kriteria sangat baik.

Berdasarkan pada kesimpulan hasil perbaikan pembelajaran dalam Penelitian Tindakan Kelas (PTK) di atas, peneliti menyadari sepenuhnya adanya keterbatasan baik waktu dan tenaga serta kemampuan yang dimiliki oleh peneliti sendiri. Ada beberapa hal yang harus diperhatikan dalam melakukan suatu penelitian pembelajaran di kelas, antara lain:

1) Guru dapat menerapkan pembelajaran dengan menerapkan model Inkuiri Terbimbing pada tema yang berbeda dan dapat mengaitkan antara materi yang sedang dipelajari dengan pengalaman yang sudah dialami peserta didik dalam kehidupan nyata.

2) Guru harus lebih banyak menciptakan ide-ide untuk pembuatan alat peraga yang sederhana akan tetapi efisien, efektif dan tepat guna sehingga pemahaman peserta didik tentang materi lebih meningkat serta menciptakan suasana pembelajaran yang menyenangkan.

3) Apabila dilihat dari tes keterampilan berpikir kritis peserta didik, guru perlu membiasakan peserta didik untuk mengerjakan soal-soal yang memerlukan proses berpikir tingkat tinggi. 
4) Hasil penelitian ini dapat dilanjutkan dan dikembangkan lebih mendalam lagi oleh pembaca dengan menggunakan peelitian lain yang sejenis yang dianggap lebih baik, tentunya dengan model lain dan pembelajaran lainnya. Hal tersebut dilakukan dalam rangka mencari solusi terbaik dalam pembelajaran tematik agar lebih baik lagi.

\section{DAFTAR PUSTAKA}

Ariani, D. N. (2018). Pengaruh Model Pembelajaran Berbasis Masalah Dengan Pendekatan Saintifik Terhadap Kemampuan Berfikir Kritis Matematis Mahasiswa/I PGMI. Muallimuna: Jurnal Madrasah Ibtidaiyah, 3(2), 108-115.

Dewi, N. L., Dantes, N., \& Sadia, I. W. (2013). Pengaruh Model Pembelajaran Inkuiri Terbimbing Terhadap Sikap Ilmiah dan Hasil Belajar IPA. Jurnal Pasca Sarjana Universitas Pendidikan Ganesha. 3, 1-10.

Haqul, M. (2016). Penerapan Model Pembelajaran Inkuiri untuk Meningkatkan Hasil Belajar IPA Kelas VA Sedolah Dasar. Jurnal Pendidikan Guru Sekolah Dasar. 4 (2), 196-206.

Haryadi, S., Djatmika, E. T., \& Setyosari, P. (2016). Pembelajaran Tematik dalam Menumbuhkan Sikap Ilmiah dan Keterampilan Berpikir Kritis Siswa SD. Seminar Nasional Pascasarjana Universitas Negeri Malang. 2, 1-10.

Hosnan. (2016). Pendekatan Saintifik dan Kontekstual dalam Pembelajaran Abad 21. Bogor: Ghalia Indonesia.

Inasyah, I. (2013). Peningkatan Keterampilan Proses dan Hasil Belajar dengan Penerapan Model Inkuiri Terbimbing di Sekolah Dasar. Jurnal Penelitian Pendidikan Guru Sekolah Dasar. 1 (2), 1-9.

Jumiati, J. (2017). Penerapan Metode Karya Wisata pada Konsep Dasar IPA MI/SD Materi Perkembangbiakan untuk Meningkatkan Motivasi Belajar Mahasiswa PGMI. Muallimuna: Jurnal Madrasah Ibtidaiyah, 2(2), 19-27.

Mulyasa, E. (2013). Pengembangan dan Implementasi Kurikulum 2013. Bandung: PT Remaja Rosdakarya.

Nurmala, S.D. (2018). Kemampuan Berpikir Kritis Siswa Kelas IV Se-Gugus 2 Purwasari dalam Membaca Pemahaman Melalui Model Fives dan Model Guided Reading. Jurnal Dinamika Pendidikan Dasar. 1 (2), 44-58.

Slameto. (2010). Belajar dan Faktor-Faktor yang Mempengaruhinya. Jakarta: Rineka Cipta.

Sulistyowati, D., Putri, S. U., \& Sumiati, T. (2016). Pengaruh Penerapan Metode Inkuiri Terhadap Sikap Ilmiah Pada Pembelajaran IPA Sekolah Dasar. Jurnal Pendidikan Ke-SD-an. 11 (1), 30-40.

Susanto, A. (2015). Teori Belajar dan Pembelajaran di Sekolah Dasar. Jakarta: Kencana. Tilaar, H. A. R., Paat, J. Ph., \& Paat, L. (2011). Pendagogik Kritis.Jakarta: Rineka Cipta. 